Article

\title{
Does Human Resource Investment for Internal Control System Enhance Future Cash Flow Predictability?
}

\author{
Jaehong Lee ${ }^{1}$ and Suyon Kim ${ }^{2, *(D)}$ \\ 1 Division of Accounting/Tax and Management Information Systems, Kyonggi University, Suwon 16227, \\ Korea; jhong@kgu.ac.kr \\ 2 Department of Accounting, Jeonbuk National University, Jeonju 54896, Korea \\ * Correspondence: sykim309@jbnu.ac.kr
}

Received: 7 September 2020; Accepted: 12 October 2020; Published: 15 October 2020

check for updates

\begin{abstract}
Generating positive long-term cash flow is vital for a firm's sustainability. In this paper, we consider the earnings in the forecasting of future cash flow from a human resource investment of an internal control system. Using the firms listed in the Korea Stock Exchange market from 2014 to 2018, we find that the current earnings are the components of cash flow forecasting, and this relationship is genuine in a firm equipped with sufficient internal control personnel and their experiences. These findings indicate that earnings are reliable when forecasting future cash flow for a firm with a well-operated foundation.
\end{abstract}

Keywords: internal control system; human resource investment; future cash flow predictability; sustainability

\section{Introduction}

In 2020, the leaders of the group of 20 major economies pledged to inject USD 5 trillion in fiscal spending into the world economy to keep economies afloat during the outbreak of coronavirus. Even more, the International Monetary Fund (IMF) has asked the G20 to double emergency financing to enhance the cash flows of the firms [1]. This news shows how actual cash helps the firms sustain themselves, because a shortage of cash will lead the firms to bankruptcies.

As we confirm from the news, cash flow is vital for a firms' growth and sustainability. Firms generally need cash to buy materials or to pay operating expenses. So, firms may go bankrupt even though they appear to be profitable. In other words, a firm's positive net income usually signal a healthy financial condition, but this can be misleading. Without cash, firms cannot purchase inventory or pay their debts. When firms delay or fail to pay their debts, they can survive in a short period of time. However, they need to have enough cash to pay in full. A firm's sustainability is ensured when the inflows exceed the outflows in the long run. As such, managing cash flow is essential to maintaining a healthy business, because effective cash flow management reduces the likelihood of bankruptcy, and improves financial outlook and sustainability [2].

The statement of cash flow is prepared based on cash-based accounting, and demonstrates the amount of money that flows within a firm over a specific accounting period, while earnings are based on the accrual-based accounting done to prepare an income statement. Accrual accounting attempts to estimate the financial impact of the various transactions in a firm's current cash flow, leading to a precise estimate of future cash flow [3]. There are several prior studies that have investigated the effect of current earnings on predicted future cash flow using data from various developed markets.

However, there are few studies based on South Korean data. South Korea is an emerging market and adopted the internal control (IC) system in 2001. Auditors are required to review the system and 
attach the operating report of IC in the audit report. Later, in 2019, to achieve investor confidence and ensure transparent financial reporting, IC was revised to a higher assurance level, from review level to audit level. It is not only mandatory for firms to report their operations, to be submitted between the day of the end of the fiscal year and the preparation of the audit report; if firms fail to receive an unqualified opinion, they may go bankrupt or be delisted.

With these enhancements, Korea is the only country that publicly discloses information on the human resource investments of the IC system. For regulators, forcing this information to be disclosed is done to provide external stakeholders with a basis for determining the extent to which the firm's IC is useful. Firms that have invested in human resources reflect the expectation that the IC will operate more effectively. Therefore, it is necessary to examine how the reliability of accounting information alters depending on the characteristics of the IC's human resources. Ge and McVay [4] examined the causes of material the weaknesses found in 261 firms from 2002 to 2004 . They assert that poor IC is usually connected to an insufficient allocation of accounting resources-for example, a lack of qualified and sufficient accounting personnel.

When a sufficient number of IC personnel exists, an appropriate segregation of duties is made, and the timeliness of the accounting function is examined and monitored. Then, the effective IC is expected to be achieved. It is inferred that firms can reduce the possibility of accounting information errors that might occur. In a similar vein, the longer average career months for personnel in charge of IC mean that they have repeated their work on IC. By doing so, the learning effect is expected to increase. Simultaneously, by improving the understanding of corporate financial information, it becomes possible to reduce accounting information errors more effectively.

While prior research focuses on the opinion of IC, this study attempts to test the IC in quantitative and qualitative manners. The quantitative measure of IC is the number of IC personnel, and the qualitative measure is the average working experience of IC personnel. Concerning quantitative measurement, the number of personnel in the IC system determines the internal strength of a firm, because having enough personnel in the IC system ensures monitoring functions [5]. In terms of qualitative measurement, when firms have more experienced personnel, they can maintain a high-quality IC system, because those experienced staff are expected to have firm- or industry-specific knowledge, useful for quality control. According to Choi et al. [5], as the firms are equipped with experienced IC personnel or with enough IC personnel, they can provide time-relevant information. The lack of an IC system may lead to corporate managers manipulating financial reporting to look better than the reality [6].

When testing the IC system's effectiveness, investments in human resources in each accounting and finance department are considered. Both departments are components of the IC system, and they oversee the practical work of the IC system in most firms. Moreover, they are directly related to the preparation of financial statements. The effective allocation of the human resource investment of the IC system can maximize the effect of a limited workforce.

In this study, we observe the forecasting power of earnings in a predicting cash flow in the context of South Korea. Furthermore, we test the effect of human resource investment in the IC system on the forecasting power of earnings in predicting future cash flow.

This study adds to the existing research. First, this is the first study to examine the effectiveness of the human resource investments of IC. Various studies that discuss whether earnings affect future cash flow predictability confirm that well-operated firms show enhanced accounting information quality.

Second, the information regarding the human resources of IC is mandated to be disclosed only in South Korea. For regulators, forcing the disclosure of information is done to provide external stakeholders with a basis for determining the extent to which the firm's IC is effective. In other words, the firms with sufficient IC personnel reflect the expectation that the IC will be operated more effectively. Therefore, it is necessary to examine the reliability of accounting information depending on the IC's characteristics. Previous studies focus on the effect of IC opinion, such as its introduction, and its material weaknesses. However, the fact that there are discriminatory differences among the firms, 
in terms of the IC personnel number and the average working experiences of IC personnel, impacts the reliability of accounting information.

Based on the fact that the ultimate goal of IC is to minimize the accounting errors, this study helps investors in considering the effective composition of IC resources when investing, auditors in performing and modifying audit procedures based on the IC operation, and regulators in utilizing IC information when supervising financial reporting.

The following is organized as follows: Section 2 explains the review of literature, Section 3 presents the data and method description, Section 4 shows the empirical results, and Section 5 presents the conclusion.

\section{Backgrounds and Hypotheses}

\subsection{Prior Research on Forecasting the Future Cash Flow}

The requirement for firms to sustain a business include the existence of a base business with a return engine that generates the expected future cash flow. If the firms are incapable of maintaining operations or fail to repay what they owe, they will ultimately go bankrupt. Therefore, the inflows and outflows of cash in financial reporting are vital sources that determine the financial health and sustainability of a firm.

FASB states that accrual-based accounting provides a better prediction of a firm's future cash flow than the current cash flow, because accrual-based accounting estimates the economic effects of various transactions that affect a firm's cash flow [7]. The studies of Dechow [8] and Dechow et al. [3] are in alignment with FASB, and suggest accrual-based accounting's role in predicting future cash flow. Both studies suggested that the earnings are a better tool than cash flow when examining short-term performance, because cash flow has some matching and timing problems compared to earnings.

Based on the model of Dechow et al. [3], Barth et al. [9] examine the role of accruals in forecasting future cash flow. They found that the accruals in the current period, such as a change in accounts receivable, a change in inventor, a change in accounts payable, a depreciation or an amortization, reflect the information of cash flow in the next period. Using 4397 samples from Spain, Arnedo et al. [10] found that the accrual-based earnings are low in error when used for future cash flow.

However, there are studies that contrast the assertion of FASB that earnings have a better ability than cash flow in forecasting future cash flow. Senan [11] examined current earnings' capability to predict future cash flow using 45 Arabian companies from 2006 to 2015. In this study, earnings were disaggregated into different accrual components that decrease their predictive ability to forecast future cash flow. Park et al. [12], using 11,696 non-financial firm samples in Korea, found that the earnings in the current period were more predictive than current cash flow when predicting future cash flow in the 1980s, yet the relationship has been reversed since 1990. After all, the capability of earnings to predict future cash flow is unsettled.

\subsection{Prior Research on Human Resource Investment for IC}

After the Enron scandal and the WorldCom crisis in the United States, the Sarbanes-Oxley Act was implemented to achieve and restore investors' confidence, and to ensure transparent financial reporting, emphasizing the significance of IC as a tool for improving financial reporting quality. The Committee of Sponsoring Organization (COSO) provides an IC framework that is used world-wide. COSO [13] suggests that sufficient personnel responsible for the IC system may positively affect the necessary control activities.

Along with these trends, South Korea adopted the IC system, with a requirement that the firms regularly report the current status of the IC system, in 2006. The Korean Financial Supervisory Service (FSS) requires all the listed firms to disclose the human resource investments of the IC system at the department level in their annual reports, which is unique among other countries. 
In detail, the listed firms in Korea must publicly disclose the number of IC personnel working, and the average working experience measured in months, in the accounting, finance, information technology (IT) and other departments. Specifically, we focus on the accounting and finance departments. The accounting department focuses on establishing accounting procedures and follows up if there are any accounting policy changes. Furthermore, the accounting department supervises the proper application of accounting procedures. The finance department regularly examines the implementation of the firm's accounting policies, accounting procedures, IC management rules, and financial reporting-related rules. Furthermore, the finance department keeps updated to meet the external regulations and internal requirements, including accounting standards changes [14].

Having sufficient IC personnel in the accounting and finance departments determines the strength of the firm's IC system. Having enough personnel in the IC system in the firm assures the appropriate segregation of tasks, a punctual review, and the monitoring of accounting functions [5]. Having more experienced IC personnel enables firms to maintain high-quality IC, because those experienced employees are expected to have a firm- and industry-specific comprehensive understanding that leads to high-quality control [15].

Using 1740 data from 2013 to 2016 in South Korea, Shin et al. [16] examined if the correlation between the human resources' characteristics, in terms of IC personnel, and the auditor-client disagreement was reinforced after the revision of the External Audit Act in 2013. They concluded that the proper investment of human resources in IC leads to less revision of earnings, meaning that it enhances the financial reporting quality.

Suh et al. [17] investigated whether external auditors change their year-end audit hours in accordance with the number of IC personnel, using 1230 firms from 2014 to 2015 in South Korea. They found that the percentage of IC personnel in total employees is negatively associated with total audit hours, especially for managers and staff auditors, who mainly perform substantive tests. This indicates that auditors can mitigate staff-shortage issues during the substantive tests at the year-end, based on the tasks performed by IC personnel. That is, the firms with sufficient IC personnel are capable of maintaining or enhancing audit quality.

Lee [18] examined the relationship between the human resource investment of IC and corporate disclosure quality, using 2234 firms from 2013 to 2016. The result of this study indicates that the firm with a higher number of IC personnel shows a lower probability of financial reporting correction, implying that the firm with a sufficient IC system increases the credibility of its disclosed financial statements.

Chang et al. [19] examined the correlation between the internal audit function quality and internal control deficiencies in operations and compliance. Using 3658 publicly unavailable data from Taiwan from 2005 to 2007, they suggested that the internal audit function staff's educational levels, professional certifications and external working experiences in auditing are negatively associated with internal control deficiencies.

\subsection{Hypothesis Development}

Predicting a firm's sustainable future cash flows is a significant function of financial statements. Among the accounts in financial statements, accrual-based earnings are one of the most critical elements in the accounting information, and are useful indicators in forecasting cash flow [7]. Since earnings are based on accrual accounting, they reduce matching and timing issues specific to cash flow data [8].

Nevertheless, accruals are often distorted because the underlying assumptions concerning determinants of earnings are changed by measurement errors that reduce the ability of revenue to predict sustainability. Furthermore, managers are at their discretion to decide the extent of information disclosed in the financial earnings reporting, as long as the generally accepted accounting principles are followed. Due to that determination made by managers, accruals are often subject to measurement errors that might adversely affect the forecasting power of earnings.

So far, we have ignored the relationship between earnings and future cash flow prediction in the emerging market. This study is meaningful in terms of testing not only the relationship between 
them, but also testing the human resource investment in the accounting and finance departments of the IC system, in order to determine its effect on the future cash flow predictability. Based on the prior research, the human resource investment of the IC system is the groundwork for producing accrual-based earnings, and will be related to the extent to which a firm accurately predicts future cash flow based on earnings.

Among IC departments, we focus on the accounting and finance departments; both departments review the external information and report significant events and trends, then apply the necessary changes, if any, to the IC system. Furthermore, those departments in the IC system oversee the practical work and are related to preparing financial statements. If the accounting and finance departments are active as part of the fundamental functioning of a firm, said firm is likely to have a high quality of financial reporting. Quantitatively and qualitatively sufficient IC human resource investment leads to reliable financial information and financial information processes. It also creates an efficient IC environment to maintain reliable accounting control, and to invest in the accounting infrastructure, which are both necessary to achieve sustainability in the market. Managers of firms with proper human resource investment in the accounting and finance departments of the IC system, meaning enough workforce as a basis, may enable sustainable decision-making. For this reason, we predict a positive correlation between the human resource investment of the IC system and the extent to which earnings can forecast future cash flow. The hypotheses are as follows.

Hypothesis 1. There is a positive relationship between earnings and future cash flow prediction.

Hypothesis 2. The effectiveness of IC operation affects the positive association between a firm's earnings and future cash flow.

Hypothesis 2.1. The positive association between a firm's earnings and future cash flow is affected by the number of IC personnel in each accounting and finance department.

Hypothesis 2.2. The positive association between a firm's earnings and future cash flow is affected by the average working experience of IC personnel in each accounting and finance department.

\section{Research Design and Sample Description}

\subsection{Measurement of Variables; Investment of Human Resources of IC Personnel}

The Law concerning the External Audit of Stock Companies in South Korea (hereinafter referred to as the External Audit Act), which is in charge of external auditing, requires that firms adhere to the specific rules and procedures for the IC system, and ensures appropriate system implementation. In 2002, the FSS published the guidelines for disclosing the operation of the internal control system. They include the total number of employees in each department, the number of IC personnel in each IC department, and the average working experiences of the IC personnel in each department, such as the accounting and finance departments, respectively.

Based on the format prescribed by the FSS, the operating departments are divided into six departments, as follows: the Audit Committee, the Board of Directors, the Accounting department, the IT department, the Finance department, and other departments. Table 1 is the actual report on the operation of the internal control of Samsung in 2018.

As a proxy for a firm's investment in the human resources of IC, the ratio of IC personnel to the total number of employees in each accounting and finance department is used. This is a quantitative measure, and involves the actual number of personnel in the accounting department (IC_Act1) and in the finance department (IC_Fin1). Furthermore, the quality of the IC personnel is considered in this study. This is a qualitative measure-the average working experience of the IC personnel in the accounting department (IC_Act2) and in the finance department (IC_Fin2). 
Table 1. Internal Control (IC) human resource investment.

\begin{tabular}{|c|c|c|c|c|c|}
\hline \multirow[b]{2}{*}{ Department } & \multirow[b]{2}{*}{ Total } & \multicolumn{3}{|c|}{ Percentage of CPA in Charge of Internal Control } & \multirow[b]{2}{*}{$\begin{array}{l}\text { Average Working Experiences } \\
\text { Measured in Months * }\end{array}$} \\
\hline & & $\begin{array}{l}\text { Internal Control Personnel } \\
\text { (A) }\end{array}$ & $\begin{array}{l}\text { Number of CPA } \\
\text { (B) }\end{array}$ & $\begin{array}{c}\text { Ratio } \\
(B / A * 100)\end{array}$ & \\
\hline Audit Committee & 3 & 3 & - & - & 62 \\
\hline Board of Directors & 11 & 11 & - & - & 33 \\
\hline Internal Control Manager & 1 & 1 & - & - & 37 \\
\hline Accounting Department & 73 & 73 & 5 & $6.8 \%$ & 146 \\
\hline Disclosure Department & 19 & 9 & - & - & 131 \\
\hline $\begin{array}{c}\text { Human Resource } \\
\text { Department }\end{array}$ & 55 & 26 & - & - & 155 \\
\hline
\end{tabular}

* Average Working Experience Measured in Months = (The sum of working experiences of internal control personnel)/(the number of internal control personnel). 


\subsection{Sample Selection}

Table 2 shows the data sampling procedures for the firms listed on the Korea Stock Exchange (KSE) market. First, to ensure homogeneity, the list is limited to December year-end firms. Simultaneously, the financial industry firms are excluded because their financial statements and the characteristics of their accounts are different from those in the manufacturing industry. We exclude the firms without financial data pertaining to one-year-ahead operating cash flow and human resource investment. The firms with negative equity are excluded due to their incapability of operating a normal business. The firms' financial data were collected from the Kis-Value database. The information on the investment of the human resources in the IC system was collected manually. For lowering the outlier effect, the extreme top and bottom $1 \%$ of the dependent variable outcomes are winsorized. The following table shows the data process for this study. The data on IC's human resource investment were manually collected. These data requirements result in a final observation of 6381 from 2014 to 2018.

Table 2. The data's description.

\begin{tabular}{|c|c|}
\hline Initial Observation from 2014 to 2018 & 20,732 \\
\hline \multicolumn{2}{|l|}{ Less: } \\
\hline Firms with the closing fiscal year in months other than December/financial companies & 10,365 \\
\hline Equity is less than zero & 1830 \\
\hline Companies without one-year-ahead operating cash flow & 1847 \\
\hline Companies with no financial statements or human resources in the IC system & 309 \\
\hline Final observation & 6381 \\
\hline
\end{tabular}

\subsection{Research Model}

To predict future cash flow, we used the regression models, as shown below. Model (1) shows the expectation that the one-year-ahead operating cash flow is related to current operating earnings if the earnings in the current period have the ability of forecasting future operating cash flow.

Next, we modified model (1) by incorporating the characteristics of human resources into the IC system to make interaction variables with earnings. Moreover, to consider variations among the firms in the same industry year, the model includes industry- and year-fixed dummies. Specifically, the following models are used for the analysis:

$$
\begin{aligned}
& F_{C F O} O_{t+1}=\beta_{0}+\beta_{1} E_{t}+\beta_{2} S_{I Z E_{t}}+\beta_{3} L E V_{t}+\beta_{4} R O A_{t}+\beta_{5} \text { GROWTH }_{t} \\
& +\beta_{6} \mathrm{MTB}_{t}+\beta_{7} \mathrm{LOSS}_{t}+\beta_{8} M O_{t}+\beta_{9} \mathrm{FO}_{t}+\mathrm{IND}+\mathrm{YR}+\varepsilon \\
& F C F O_{t+1}=\beta_{0}+\beta_{1} E_{t}+\beta_{2} I C 1, I C 2_{t}+\beta_{3} E_{t} \times I C 1, I C 2_{t}+\beta_{4} S I Z E_{t}+\beta_{5} L E V_{t} \\
& +\beta_{6} \text { ROA }_{t}+\beta_{7} \text { GROWTH }_{t}+\beta_{8} \text { MTB }_{t}+\beta_{9} \text { LOSS }_{t} \\
& +\beta_{10} M O_{t}+\beta_{11} F_{t}++\mathrm{IND}+\mathrm{YR}+\varepsilon
\end{aligned}
$$

where $\mathrm{FCFO}=$ operating cash flow, measured as net cash flow from operating activities obtained from the cash flow statement, adjusted for extraordinary items and discontinued operations divided by the average of total assets between the beginning and the end of the fiscal year. $\mathrm{E}=$ earnings before extraordinary items, divided by the average of total assets between the beginning and the end of the fiscal year. IC1 = IC_Act1 and IC_Fin1, the number of IC personnel in the accounting and finance departments, respectively. IC2 = IC_Act2 and IC_Fin2, the average working experiences measured in months of IC personnel in accounting and finance departments, respectively. SIZE $=\mathrm{Ln}$ (total assets), $\mathrm{ROA}=$ net income/total assets, $\mathrm{LEV}=$ total debt/total assets, GROWTH $=$ (sales - sales in the prior year)/sales in prior year, MTB = market value/total equity, LOSS = 1 for a company with losses, and 0 otherwise, $\mathrm{MO}=$ percentage of shares held by largest shareholders, $\mathrm{FO}=$ percentage of shares held by foreign investors, $\mathrm{IND}=$ industry dummies and $\mathrm{YR}=$ year dummies. 
Based on the prior research, control variables such as firm size and financial leverage are used. By doing so, the bias from the possible omitted variable is probably minimized. SIZE, which represents the firm size, is used and measured as the natural log of total assets. For controlling firms' performances and risks, ROA and Loss are included in the model, respectively. To control arise from the firm's ownership structure, MO and FO are included in the model. To control the volatility by industry, an industry dummy is included. A year dummy is included in the model to manage the volatility caused by specific economic conditions within a particular year.

One-year-ahead operating cash flow is estimated by the current operating earnings using model 1. If the earnings in the current period have a predictive ability in terms of the future operating cash flow, $\beta_{1}$ will represent a positive coefficient. Then, we modified model 1 by incorporating the human resource investment of IC into the accounting and finance departments, to make interaction variables with earnings, respectively. $\beta_{3}$ in model 2 is the interaction variable between earnings and the human resource investment of IC, implying the effects of the human resource investment of IC on forecasting the future operating cash flow (in other words, the power of current earnings to predict future operating cash flow as the human resource investment of IC increases). The model includes industry- and year-fixed dummies to allow variations among the firms in the same observed industry years.

\section{Empirical Results}

\subsection{Descriptive Statistics}

The descriptive statistics for investigating the current earnings' ability, depending on the IC's human resource investment, to predict future cash flow are presented in Table 3. The average numbers of IC personnel in the accounting and finance departments are 2.913 and 2.220, respectively. The working experiences of the IC personnel in the accounting and finance departments are 0.002 and 0.001 .

Table 3. Descriptive statistics.

\begin{tabular}{cccccc}
\hline Variables & Mean & STD & Min & Median & Max \\
\hline FCFO & 0.026 & 0.088 & -1.541 & 0.000 & 0.779 \\
E & 0.005 & 0.124 & -2.189 & 0.008 & 2.914 \\
IC_Act1 & 2.913 & 2.271 & 0.000 & 4.190 & 7.462 \\
IC_Fin1 & 2.220 & 2.340 & 0.000 & 0.000 & 7.099 \\
IC_Act2 & 0.002 & 0.003 & 0.000 & 0.001 & 0.042 \\
IC_Fin2 & 0.001 & 0.002 & 0.000 & 0.000 & 0.028 \\
\hline
\end{tabular}

Notes-Variable definitions: $\mathrm{CFO}=$ operating cash flow, defined as net cash flow from operating activities obtained from the cash flow statement adjusted for the extraordinary item and discontinued operations divided by the average of total assets between the beginning and the end of the fiscal year; $\mathrm{E}=$ operating income before extraordinary items divided by the average of total assets between the beginning and the end of the fiscal year; IC_Act1 = number of IC personnel in the accounting department; IC_Fin1 = number of IC personnel in the finance department; IC_Act2 = average working experience of IC personnel in the accounting department in months; IC_Fin2 = average working experience of IC personnel in the finance department in months.

Table 4 shows the Pearson correlation matrix for the significant variables used in this study. It shows a significant positive association between future operating cash flow, earnings in the current period, and human resources invested in the accounting and finance departments. It implies that the current period's earnings and human resource investments help predict future operating cash flow. 
Table 4. A correlation matrix.

\begin{tabular}{|c|c|c|c|c|c|c|}
\hline & (1) & (2) & (3) & (4) & (5) & (6) \\
\hline (1) FCFO & 1.000 & $\begin{array}{c}0.273 \\
<0.0001\end{array}$ & $\begin{array}{c}0.172 \\
<0.0001\end{array}$ & $\begin{array}{c}0.109 \\
<0.0001\end{array}$ & $\begin{array}{l}-0.047 \\
<0.0001\end{array}$ & $\begin{array}{l}-0.057 \\
<0.0001\end{array}$ \\
\hline (2) $\mathrm{E}$ & & 1.000 & $\begin{array}{l}0.031 \\
0.002\end{array}$ & $\begin{array}{l}0.007 \\
0.455\end{array}$ & $\begin{array}{l}-0.184 \\
<0.0001\end{array}$ & $\begin{array}{l}-0.180 \\
<0.0001\end{array}$ \\
\hline (3) IC_Act1 & & & 1.000 & $\begin{array}{c}0.728 \\
<0.0001\end{array}$ & $\begin{array}{c}0.407 \\
<0.0001\end{array}$ & $\begin{array}{c}0.328 \\
<0.0001\end{array}$ \\
\hline (4) IC_Fin1 & & & & 1.000 & $\begin{array}{c}0.258 \\
<0.0001\end{array}$ & $\begin{array}{c}0.457 \\
<0.0001\end{array}$ \\
\hline (5) IC_Act2 & & & & & 1.000 & $\begin{array}{c}0.678 \\
<0.0001\end{array}$ \\
\hline (6) IC_Fin2 & & & & & & 1.000 \\
\hline
\end{tabular}

(1) See Table 2 for definitions of the variables.

\subsection{Main Results}

Table 5 presents the multivariate test result of hypothesis 1 based on the estimation of Equations (1) and (2). For Equation (2) in Table 4, E's coefficient is 0.128 and the t-value of 5.810, reporting significantly positive (+) value. It means that earnings have forecasting power of future operating cash flow. This result proves the first hypothesis that there is a positive association between earnings and future cash flow. In accordance with the study of Nam [20], it is estimated that the forecasting power of earning for the future is positively associated.

Table 5. Regression results: Relationship between earnings and future cash flow prediction.

\begin{tabular}{|c|c|c|}
\hline Panel A. H1 & & \\
\hline Variables & Coefficient & $t$-Value \\
\hline Intercept & -0.160 & $-8.440 * * *$ \\
\hline E & 0.128 & $5.810^{* * *}$ \\
\hline$S I Z E$ & 0.007 & $9.880^{* * *}$ \\
\hline$L E V$ & 0.000 & -0.190 \\
\hline ROA & -0.017 & -0.990 \\
\hline GROWTH & -0.006 & -1.410 \\
\hline MTB & 0.000 & -1.120 \\
\hline LOSS & -0.022 & $-8.300^{* * *}$ \\
\hline MO & 0.029 & $4.830^{* * *}$ \\
\hline$F O$ & 0.062 & $6.060^{* * *}$ \\
\hline Industry Dummy & \multicolumn{2}{|c|}{ Included } \\
\hline Year Dummy & \multicolumn{2}{|c|}{ Included } \\
\hline F-value & \multicolumn{2}{|c|}{$58.45^{* * *}$} \\
\hline Adj. $\mathrm{R}^{2}$ & \multicolumn{2}{|c|}{0.129} \\
\hline Observations & \multicolumn{2}{|c|}{6381} \\
\hline
\end{tabular}

(1) *** indicate significance at the $1 \%$ level. (2) See Table 2 for definitions of other variables.

Table 6 presents the results of the multivariate test of Hypothesis 2 based on the estimation in Equation (2). Table 6 shows the results for the accounting and finance departments. In panel A in Table 6, the coefficients for E were 0.281, with a t-value of 9.040, and 0.299, with a t-value of 9.520, in the accounting and finance departments, respectively, reporting a significantly positive (+) value. Furthermore, the coefficient of the interaction variable between the earnings and IC personnel in 
accounting is 5.495, with a t-value of 3.630, and the interaction variable between the earnings and IC personnel in finance is 4.003 , and the $t$-value is 1.880 . The results show that firms with sufficient IC personnel are likely to predict future operating cash flow, proving Hypothesis 2.1.

Table 6. Regression results: The effect of IC personnel on the relationship between earnings and future cash flow prediction.

\begin{tabular}{|c|c|c|c|c|}
\hline \multicolumn{5}{|c|}{ Panel A. H2-Number of IC Personnel } \\
\hline \multirow{2}{*}{ Variables } & \multicolumn{2}{|c|}{ Accounting Department } & \multicolumn{2}{|c|}{ Finance Department } \\
\hline & Coefficient & $t$-Value & Coefficient & $t$-Value \\
\hline Intercept & -0.202 & $-7.900 * * *$ & -0.207 & $-8.330^{* * *}$ \\
\hline$E^{-1}$ & 0.281 & $9.040^{* * *}$ & 0.299 & $9.520^{* * *}$ \\
\hline IC_Act1 & -0.028 & -0.060 & & \\
\hline$E \times I C \_A c t 1$ & 5.495 & $3.630 * * *$ & & \\
\hline IC_Fin1 & & & -0.487 & -0.690 \\
\hline$E \times I C \_$Fin1 & & & 4.003 & $1.880^{* *}$ \\
\hline$S I Z E$ & 0.009 & $9.630 * * *$ & 0.010 & $10.390 * * *$ \\
\hline$L E V$ & 0.000 & -0.230 & 0.000 & -1.290 \\
\hline ROA & -0.143 & $-5.920 * * *$ & -0.133 & $-5.360 * *$ \\
\hline GROWTH & -0.010 & -1.860 & -0.011 & -2.030 \\
\hline MTB & 0.000 & -0.760 & -0.001 & $-2.130 * *$ \\
\hline LOSS & -0.025 & $-7.470 * * *$ & -0.024 & $-7.120 * * *$ \\
\hline$M O$ & 0.038 & $5.060 * * *$ & -0.008 & $-4.700^{* * *}$ \\
\hline$F O$ & 0.081 & $6.540^{* * *}$ & 0.042 & $5.580 * * *$ \\
\hline Industry Dummy & \multicolumn{2}{|c|}{ Included } & \multicolumn{2}{|c|}{ Included } \\
\hline Year Dummy & \multicolumn{2}{|c|}{ Included } & \multicolumn{2}{|c|}{ Included } \\
\hline F-value & \multicolumn{2}{|c|}{$57.95 * * *$} & \multicolumn{2}{|c|}{$54.09 * * *$} \\
\hline Adj. $R^{2}$ & \multicolumn{2}{|c|}{0.176} & \multicolumn{2}{|c|}{0.178} \\
\hline Observations & \multicolumn{2}{|c|}{6381} & \multicolumn{2}{|c|}{6381} \\
\hline
\end{tabular}

Panel B. H2-Working Experiences

\begin{tabular}{|c|c|c|c|c|}
\hline \multirow{2}{*}{ Variables } & \multicolumn{2}{|c|}{ Accounting Department } & \multicolumn{2}{|c|}{ Finance Department } \\
\hline & Coefficient & $t$-Value & Coefficient & $t$-Value \\
\hline Intercept & -0.211 & $-8.850 * * *$ & -0.209 & $-8.850 * * *$ \\
\hline$E^{1}$ & 0.232 & $6.820 * * *$ & 0.271 & $8.360^{* * *}$ \\
\hline IC_Act2 & 0.001 & 0.870 & & \\
\hline$E \times \overline{I C} \_$Act2 & 0.018 & $4.030^{* * *}$ & & \\
\hline IC_Fin2 & & & -0.001 & -0.970 \\
\hline$E \times \overline{I C} \_$Fin 2 & & & 0.007 & $1.680 *$ \\
\hline$S I \bar{Z} E$ & 0.009 & $10.460^{* * *}$ & 0.009 & $10.620^{* * *}$ \\
\hline$L E V$ & 0.000 & -0.190 & 0.000 & -0.170 \\
\hline ROA & -0.128 & $-5.420 * * *$ & -0.123 & $-5.210 * * *$ \\
\hline GROWTH & -0.009 & -1.590 & -0.009 & -1.560 \\
\hline MTB & 0.000 & -0.730 & 0.000 & -0.960 \\
\hline LOSS & -0.022 & $-6.500^{* * *}$ & -0.024 & $-6.970 * * *$ \\
\hline $\mathrm{MO}$ & 0.038 & $5.060^{* * *}$ & 0.038 & $5.170 * * *$ \\
\hline$F O$ & 0.076 & $6.140^{* * *}$ & 0.078 & $6.260^{* * *}$ \\
\hline Industry Dummy & \multicolumn{2}{|c|}{ Included } & \multicolumn{2}{|c|}{ Included } \\
\hline Year Dummy & \multicolumn{2}{|c|}{ Included } & \multicolumn{2}{|c|}{ Included } \\
\hline F-value & \multicolumn{2}{|c|}{$58.08 * * *$} & \multicolumn{2}{|c|}{$57.38^{* * *}$} \\
\hline Adj. $\mathrm{R}^{2}$ & \multicolumn{2}{|c|}{0.1771} & \multicolumn{2}{|c|}{0.175} \\
\hline Observations & \multicolumn{2}{|c|}{6381} & \multicolumn{2}{|c|}{6381} \\
\hline
\end{tabular}

$(1)^{*}, * *$ and ${ }^{* * *}$ indicate significance at the $10 \%, 5 \%$ and $1 \%$ levels, respectively. (2) See Table 2 for definitions of other variables. 
The purpose of IC is to improve and enhance the reliability of the accounting information in a firm. To satisfy this purpose, the IC should be operated effectively, and the operation of the IC will be influenced by the personnel in charge, which is recommended by the Committee of Sponsoring Organizations (COSO). Thus, the firms that are equipped with sufficient IC personnel segregate tasks appropriately, and monitor accounting functions [5], thus predicting future operating cash flow via earnings.

Panel B shows that the coefficient of the interaction variable between earnings and the working experiences of IC personnel in the accounting department is $5.495(t=3.630)$, and the interaction variable between earnings and the working experiences of IC personnel in finance was $4.003(t=1.880)$. The result shows that the working experiences of personnel in each accounting and finance department foster a high predictive ability for future operating cash flow through earnings, thus validating Hypothesis 2.2.

These results suggest that both the quantitative and qualitative measures of the IC personnel effectively help earnings to predict future operating cash flow. In other words, more staff, and the proper training, education and experience level of IC personnel, are effective factors when predicting future cash flows, since they are obliged to monitor and detect possible occurrences of fraud or irregularities. Furthermore, this result suggests that the proportion and working experiences of IC personnel are critical factors in preserving the quality of IC, which influences the financial reporting quality.

\subsection{Additional Analysis}

Table 7 is the result of testing the hypotheses by separating the firms into two categories, Big4-audited firms and non-Big4-audited firms. Big 4 is an abbreviation for four big accounting firms, and these are PWC, KPMG, Ernst \& Young and Deloitte. There is a discriminative effect between firms audited by Big4 and those audited by non-Big4, supported by previous studies [18]. Big4 accounting firms are big in size, and provide a higher level of audit quality than non-Big4 accounting firms. Therefore, the firms audited by Big4 are expected to be well-equipped internally.

In Table 7, panel A shows that the coefficient for $\mathrm{E} \times \mathrm{IC}$ _Act1 audited by Big4 accounting firms is 12.355 , with a $t$-value of 4.700 , reporting a significantly positive $(+)$ value (significant at the $1 \%$ level). However, the coefficient for $\mathrm{E} \times \mathrm{IC} \_$Act1 audited by non-Big4 accounting firms is the negative value of 0.851 , reporting no significance. Panel A also shows the coefficient of $\mathrm{E} \times \mathrm{IC}$ _Fin1. The value of $\mathrm{E} \times \mathrm{IC} \_$Fin1 audited by Big4 accounting firms is 11.083 , with a t-value of 3.320, while the value of $\mathrm{E}$ $\times$ IC_Fin1 audited by non-Big4 firms is 0.716 , with no significance. This outcome suggests that the firms with a sufficiently large workforce in their accounting and finance departments, audited by Big4 accounting firms, exhibit the high predictability of their future operating cash flow through earnings.

In Table 7, panel B shows that the coefficient for $\mathrm{E} \times$ IC_Act2 audited by Big4 accounting firms is 0.024 , with a t-value of 4.200 , reporting a significantly positive $(+)$ value (significant at the $1 \%$ level). However, the coefficient of $\mathrm{E} \times \mathrm{IC} \_$Act2 is 0.001 , with no significance. The coefficient for $\mathrm{E} \times \mathrm{IC}$-Fin2, audited by Big 4 accounting firms, is 0.014 , with a t-value of 2.540 , which is positively significant, while the coefficient for $\mathrm{E} \times$ IC_Fin2 is 0.003 , with no significance. These results validate the hypotheses for the firms audited by Big4 accounting firms. It is also inferred that the firms audited by Big4 accounting firms are internally controllable, with the proper number of IC personnel with experience, yielding enhanced financial information reliability.

In Table 7, panel A shows that the coefficient for $\mathrm{E} \times$ IC_Act1 audited by Big4 accounting firms is 12.355 , with a t-value of 4.700 , reporting a significantly positive (+) value (significant at $1 \%$ level). However, the coefficient for $\mathrm{E} \times \mathrm{IC} \_$Act1, audited by non-Big4 accounting firms, is the negative value of 0.851 , reporting no significance. Panel A also shows the coefficient of $\mathrm{E} \times \mathrm{IC}$ _Fin1. The value of $\mathrm{E} \times$ IC_Fin1 audited by Big4 accounting firms is 11.083, with a t-value of 3.320, while the value for $\mathrm{E} \times$ IC_Fin1 audited by non-Big4 is 0.716 , with no significance. This outcome suggests that the firms with a sufficiently large workforce in their accounting and finance departments, audited by Big4 accounting firms, show an enhancement in the predictability of their future operating cash flow via earnings. 
Table 7. Additional analysis: The effect of IC personnel on the relationship between earnings and future cash flow prediction. Big4 vs. Non-Big4.

\begin{tabular}{|c|c|c|c|c|}
\hline \multicolumn{5}{|c|}{ Panel A. Number of IC Personnel } \\
\hline \multirow{3}{*}{ Variables } & \multicolumn{4}{|c|}{ Accounting Department } \\
\hline & \multicolumn{2}{|c|}{ BIG4 } & \multicolumn{2}{|c|}{ Non-BIG4 } \\
\hline & Coefficient & $t$-Value & Coefficient & $t$-Value \\
\hline Intercept & -0.116 & $-3.790 * * *$ & -0.358 & $-6.780 * * *$ \\
\hline$E^{1}$ & 0.260 & $7.270 * * *$ & 0.295 & $4.760 * * *$ \\
\hline IC_Act1 & 0.948 & 1.560 & -0.383 & -0.590 \\
\hline$E \times I C \_A c t 1$ & 12.335 & $4.700^{* * *}$ & -0.851 & -0.370 \\
\hline Control Variables & \multicolumn{2}{|c|}{ Included } & \multicolumn{2}{|c|}{ Included } \\
\hline Industry Dummy & \multicolumn{2}{|c|}{ Included } & \multicolumn{2}{|c|}{ Included } \\
\hline Year Dummy & \multicolumn{2}{|c|}{ Included } & \multicolumn{2}{|c|}{ Included } \\
\hline F-value & \multicolumn{2}{|c|}{$23.39 * * *$} & \multicolumn{2}{|c|}{$29.92 * * *$} \\
\hline Adj. $R^{2}$ & \multicolumn{2}{|c|}{0.148} & \multicolumn{2}{|c|}{0.178} \\
\hline \multirow[t]{2}{*}{ Observations } & \multicolumn{2}{|c|}{3069} & \multicolumn{2}{|c|}{3312} \\
\hline & & Finance & epartment & \\
\hline \multirow[t]{2}{*}{ Variables } & \multicolumn{2}{|c|}{ BIG4 } & No & IG4 \\
\hline & Coefficient & $t$-Value & Coefficient & $t$-Value \\
\hline Intercept & -0.116 & $-3.880 * * *$ & -0.354 & $-6.890^{* * *}$ \\
\hline$E^{1}$ & 0.276 & $7.320 * * *$ & 0.298 & $4.760^{* * *}$ \\
\hline IC_Fin1 & 1.638 & 1.480 & -1.067 & -1.110 \\
\hline$E \times I C \_F i n 1$ & 11.083 & $3.320 * * *$ & 0.716 & 0.220 \\
\hline Control Variables & Inc & led & & ded \\
\hline Industry Dummy & Inc & led & & ded \\
\hline Year Dummy & Inc & led & & ded \\
\hline F-value & 22. & & & $* * *$ \\
\hline Adj. $R^{2}$ & & & & \\
\hline Observations & & & & \\
\hline Panel B. Working E & periences & & & \\
\hline & & Accountir & Department & \\
\hline Variables & & & No & IG4 \\
\hline & Coefficient & $t$-Value & Coefficient & $t$-Value \\
\hline Intercept & -0.110 & $-3.810 * * *$ & -0.369 & $-7.420 * * *$ \\
\hline$E^{1}$ & 0.181 & $4.790 * * *$ & 0.292 & $4.250^{* * *}$ \\
\hline IC_Act2 & 0.000 & 0.290 & 0.000 & 0.310 \\
\hline$E \times I \bar{C} \_$Act 2 & 0.024 & $4.200 * * *$ & 0.001 & 0.160 \\
\hline Control Variables & Inc & & & ded \\
\hline Industry Dummy & Inc & led & & ded \\
\hline Year Dummy & Inc & led & & ded \\
\hline F-value & 23. & & & $* * *$ \\
\hline Adj. $R^{2}$ & & & & \\
\hline Observations & & & & \\
\hline & & Finance & epartment & \\
\hline Variables & & & No & IG4 \\
\hline & Coefficient & $t$-Value & Coefficient & $t$-Value \\
\hline Intercept & -0.105 & $-3.690 * * *$ & -0.368 & $-7.430^{* * *}$ \\
\hline E & 0.215 & $5.900 * * *$ & 0.286 & $4.400 * * *$ \\
\hline IC_Fin2 & -0.002 & $-2.070 * *$ & -0.001 & -0.640 \\
\hline$E \times I C \_$Fin 2 & 0.014 & $2.540 * *$ & 0.003 & 0.430 \\
\hline Control Variables & Inc & & & ded \\
\hline Industry Dummy & Inc & led & & ded \\
\hline Year Dummy & Inc & & & ded \\
\hline F-value & 22. & & & $* * *$ \\
\hline Adj. $R^{2}$ & & & & \\
\hline Observations & & & & \\
\hline
\end{tabular}

(1) ${ }^{* *}$ and ${ }^{* * *}$ indicate significance at the $5 \%$ and $1 \%$ levels, respectively. (2) See Table 2 for definitions of other variables. 
In Table 7, panel B shows that the coefficient for $\mathrm{E} \times$ IC_Act2, audited by Big4 accounting firms, is 0.024 , with a t-value of 4.200 , reporting a significantly positive (+) value (significant at the $1 \%$ level). However, the coefficient of $\mathrm{E} \times \mathrm{IC} \_$Act2 is 0.001 , with no significance. The coefficient for $\mathrm{E} \times \mathrm{IC}$-Fin2 audited by Big4 accounting firms is 0.014 , with a t-value of 2.540 , which is positively significant, while the coefficient for $\mathrm{E} \times$ IC_Fin2 is 0.003 with no significance. These results validate the hypotheses for the firms audited by Big4 accounting firms. It is also inferred that the firms audited by Big4 accounting firms are internally controllable, with the proper numbers of IC personnel with experience yielding enhanced financial information reliability.

\subsection{The Effect of Firm Size}

Table 8 is the result of empirical findings on the firm-fixed effect. Panel A shows that the coefficient of $\mathrm{E} \times$ IC_Act1 $\left(\mathrm{E} \times \mathrm{IC} \_\right.$Fin1) is 5.092 (4.035), with a t-value of 3.350 (1.890), which is positively significant. Panel B shows that the coefficient of $\mathrm{E} \times \mathrm{IC} \_$Act2 $\left(\mathrm{E} \times \mathrm{IC} \_\right.$Fin2) is $0.238(0.008)$ at $1 \%$ significance. These results are in accordance with the main result. Overall, the results support the strong evidence that the firms with enough IC personnel can predict future cash flow through earnings, even after firms are controlled. At the same time, IC personnel with work experiences play a significant role in enhancing financial reporting quality, after firms are controlled. These results validate the hypotheses of our study.

Table 8. Additional analysis: Firm-fixed effects.

\begin{tabular}{|c|c|c|c|c|}
\hline \multicolumn{5}{|c|}{ Panel A. Number of IC Personnel } \\
\hline \multirow{2}{*}{ Variables } & \multicolumn{2}{|c|}{ Accounting Department } & \multicolumn{2}{|c|}{ Finance Department } \\
\hline & Coefficient & $t$-Value & Coefficient & $t$-Value \\
\hline $\mathrm{E}$ & 0.293 & $9.390^{* * *}$ & 0.310 & $9.880 * * *$ \\
\hline IC_Act1 & -1.356 & $-3.320 * * *$ & & \\
\hline$E \times I C \_A c t 1$ & 5.092 & $3.350 * * *$ & & \\
\hline IC_Fin1 & & & -2.052 & $-3.040^{* * *}$ \\
\hline$E \times I C \_$Fin 1 & & & 4.035 & $1.890 * *$ \\
\hline Control Variables & \multicolumn{2}{|c|}{ Included } & \multicolumn{2}{|c|}{ Included } \\
\hline Industry Dummy & \multicolumn{2}{|c|}{ Included } & \multicolumn{2}{|c|}{ Included } \\
\hline Year Dummy & \multicolumn{2}{|c|}{ Included } & \multicolumn{2}{|c|}{ Included } \\
\hline F-value & \multicolumn{2}{|c|}{$100.52^{* * *}$} & \multicolumn{2}{|c|}{$99.69 * * *$} \\
\hline Adj. $\mathrm{R}^{2}$ & \multicolumn{2}{|c|}{0.275} & \multicolumn{2}{|c|}{0.273} \\
\hline Observations & \multicolumn{2}{|c|}{6381} & \multicolumn{2}{|c|}{6381} \\
\hline \multicolumn{5}{|c|}{ Panel B. Working Experiences } \\
\hline \multirow{2}{*}{ Variables } & \multicolumn{2}{|c|}{ Accounting Department } & \multicolumn{2}{|c|}{ Finance Department } \\
\hline & Coefficient & $t$-Value & Coefficient & $t$-Value \\
\hline E & 0.000 & $6.960^{* * *}$ & 0.271 & $8.360 * * *$ \\
\hline IC_Act2 & 0.020 & -0.320 & & \\
\hline$E \times I C \_A c t 2$ & 0.238 & $4.400 * * *$ & & \\
\hline IC_Fin2 & & & -0.001 & -0.970 \\
\hline$E \times \overline{I C} \_$Fin 2 & & & 0.008 & $1.680^{* * *}$ \\
\hline Control Variables & \multicolumn{2}{|c|}{ Included } & \multicolumn{2}{|c|}{ Included } \\
\hline Industry Dummy & \multicolumn{2}{|c|}{ Included } & \multicolumn{2}{|c|}{ Included } \\
\hline Year Dummy & \multicolumn{2}{|c|}{ Included } & \multicolumn{2}{|c|}{ Included } \\
\hline F-value & \multicolumn{2}{|c|}{$99.76^{* * *}$} & \multicolumn{2}{|c|}{$99.97 * * *$} \\
\hline Adj. $\mathrm{R}^{2}$ & \multicolumn{2}{|c|}{0.274} & \multicolumn{2}{|c|}{0.272} \\
\hline Observations & \multicolumn{2}{|c|}{6381} & \multicolumn{2}{|c|}{6381} \\
\hline
\end{tabular}

(1) ${ }^{* *}$ and $\overline{* * *}$ indicate significance at the $5 \%$ and $1 \%$ levels, respectively. (2) See Table 2 for definitions of other variables. 


\subsection{The Alternative Measure-Aggregate Measurement}

Table 9 shows the additional analysis, using an aggregate measure of the number of IC personnel and their working experiences based on the sum of each accounting and finance department. In Table 8 , the coefficients for $\mathrm{E} \times$ IC_Total1 and $\mathrm{E} \times$ IC_Total2 are 5.958 and 3.452, reporting a significantly positive (+) value (significant at the $1 \%$ level).

Table 9. Additional analysis: Aggregate measure.

\begin{tabular}{|c|c|c|c|c|}
\hline \multirow{2}{*}{ Variables } & \multicolumn{2}{|c|}{ Number of Personnel } & \multicolumn{2}{|c|}{ Working Experiences } \\
\hline & Coefficient & $t$-Value & Coefficient & $t$-Value \\
\hline Intercept & -0.170 & $-8.540^{* * *}$ & -0.017 & $-6.270 * * *$ \\
\hline$E^{1}$ & 0.122 & $5.540^{* * *}$ & 0.052 & $2.390^{* *}$ \\
\hline IC_Total1 & 0.690 & $2.760^{* * *}$ & & \\
\hline$E \times \overline{I C} \_$Total1 & 5.958 & $7.160 * * *$ & & \\
\hline IC_Total2 & & & 0.001 & $8.17^{* * *}$ \\
\hline$E \times I C \_$Total2 & & & 0.021 & $12.980 * * *$ \\
\hline Control Variables & \multicolumn{2}{|c|}{ Included } & \multicolumn{2}{|c|}{ Included } \\
\hline Industry Dummy & \multicolumn{2}{|c|}{ Included } & \multicolumn{2}{|c|}{ Included } \\
\hline Year Dummy & \multicolumn{2}{|c|}{ Included } & \multicolumn{2}{|c|}{ Included } \\
\hline F-value & \multicolumn{2}{|c|}{$56.04^{* * *}$} & \multicolumn{2}{|c|}{$71.45^{* * *}$} \\
\hline Adj. $R^{2}$ & \multicolumn{2}{|c|}{0.134} & \multicolumn{2}{|c|}{0.147} \\
\hline Observations & \multicolumn{2}{|c|}{6381} & \multicolumn{2}{|c|}{6381} \\
\hline
\end{tabular}

The results suggest that the firms with a sufficient number of IC personnel in their accounting and finance departments are likely to predict future cash flow through earnings. In other words, an adequate number of IC personnel plays a role in enhancing the reliability of financial accounting information. In the same vein, the IC personnel's higher average working experience mean that they work iteratively, thereby maximizing the learning effect. Furthermore, they become adept at understanding accounting information, leading to reliability in financial accounting information.

\section{Conclusions}

The flow of actual cash is critical for a firm's sustainability, as we can confirm from various recent news reports regarding boosting cash in various countries. A firm's future cash flow involves evaluating a firm's current value, and is strongly predicted by the accounting earnings [21]. In this study, we invested the relationship between the accounting earnings and future cash flow predictability in accordance with the human resource investment of the IC system using 6381 items of information from South Korea.

For transparency and improving the quality of financial reporting, the investment of human resources in the IC system is required. We find that the number of IC personnel (the quantitative measure of investment) in each accounting and finance department affects the relationship between the current earnings and future cash flow prediction. Simultaneously, the working experiences of IC personnel (the qualitative measure of investment) in each accounting and finance department influence the relationship between the current earnings and future cash flow prediction. To summarize, in the fundamentally well-operated firms with enough staff with sufficient working experience, future cash flow is positively predicted through current earnings.

This paper has limitations. Since the data concerning human resources in ICs are limited in Korea, it can be difficult to generalize empirical results to other countries. In addition, there is a possibility of an omitted control variable problem that may lead to errors.

However, this study adds to the existing research. First, this is the first study to examine the effectiveness of the human resource investment of IC. Though various studies discuss whether 
earnings affect future cash flow predictability, we confirm that well-operated firms enhance the quality of information.

Second, the disclosure of information regarding the human resources of IC is mandated only in South Korea. For regulators, forcing the disclosure of information is done to provide external stakeholders with a basis for determining the extent to which the firm's IC is effective. In other words, firms with sufficient IC personnel reflect the expectation that the IC will be operated more effectively. Therefore, it is necessary to examine the reliability of accounting information depending on the characteristics of IC. Previous studies focus on the effect of the perception of IC, such as its introduction and material weaknesses. However, the fact that there are discriminatory differences among the firms, in terms of the IC personnel number and the average working experience of IC personnel, impacts the reliability of the accounting information.

Based on the fact that the ultimate goal of IC is to minimize accounting errors, this study outlines the implications for investors to consider when investing, in terms of the effective composition of IC resources, for auditors to consider when performing and modifying audit procedures based on the IC's operation, and for regulators to utilize when supervising financial reporting.

Author Contributions: Conceptualization, J.L.; methodology, J.L.; software, J.L.; validation, J.L. and S.K.; formal analysis, J.L.; investigation, J.L.; resources, J.L.; data curation, J.L.; writing-Original draft preparation, S.K.; writing-Review and editing, S.K.; supervision, J.L. and S.K. The two authors contributed equally to the manuscript. All authors have read and agreed to the published version of the manuscript.

Funding: This research received no external funding.

Conflicts of Interest: The authors declare no conflict of interest.

\section{References}

1. G20 Leaders to Inject \$8 Trillion into Global Economy to Fight Coronavirus; ABC News: New York, NY, USA, 2020; Volume 3, p. 26.

2. Patel, U. Cash Management at Indian Oil Corporation Ltd. Master's Thesis, DY. Patil University, Mumbai, India, 2010.

3. Dechow, P.M.; Kothari, S.P.; Watts, R.L. The Relation between Earnings and cash-flows. J. Account. Econ. 1998, 25, 133-168. [CrossRef]

4. Ge, W.; McVay, S. The disclosure of material weakness in internal control after the Sarbanes-Oxley Act. Account. Horiz. 2005, 19, 137-158. [CrossRef]

5. Choi, J.H.; Choi, S.; Hogan, C.; Lee, J. The Effect of Human Resource Investment in Internal Control on the Disclosure of Internal Control Weaknesses. Audit. A J. Pract. Theory 2013, 32, 169-199. [CrossRef]

6. Niemeier, C. Remarks before the National Association of State Boards of Accountancy, Atlanta, GA. 2006. Available online: www.pcaobus.org (accessed on 1 August 2020).

7. Financial Accounting Standard Board. Statement of Financial Accounting Concepts No.1, Objectives of Financial Reporting by Business Enterprise; Financial Accounting Standard Board: Norwalk, CT, USA, 1978.

8. Dechow, P.M. Accounting earnings and cash flows as measures of firm performance: The role of accounting accruals. J. Account. Econ. 1994, 18, 3-42. [CrossRef]

9. Barth, M.E.; Cram, D.; Nelson, K. Accruals and the prediction of future cash flows. Account. Rev. 2001, 76, 27-58. [CrossRef]

10. Arnedo, L.; Lizarraga, F.; Sánchez, S. The role of accounting accruals for the prediction of future cash flows: Evidence from Spain. SERIEs 2012, 3, 499-520. [CrossRef]

11. Senan, N.A.M. Ability of earnings and cash flow in forecasting future cash flows: A study in the context of Saudi Arabia. Acad. Account. Financ. Stud. J. 2019, 23, 2-13.

12. Park, J.K.; Hong, Y.E.; Lee, M.Y. The ability to predict future operating cash flows and matching principle. Account. Inf. Rev. 2015, 33, 217-236.

13. COSO (The Committee of Sponsoring Organizations). Internal Control, Integrated Framework. 2006. Available online: http://www.coso.org (accessed on 1 August 2020). 
14. Shin, I.H.; Lee, H.Y.; Lee, E.C. The effect of quantitative and qualitative characteristics of investment in internal accounting management systems on analysts' forecast: An analysis on financial department. Study Account. Tax. Audit. 2014, 56, 57-88.

15. Shin, I.H.; Lee, H.Y.; Lee, H.A.; Son, M. How does human resource investment in internal control affect audit report lag? Asia-Pac. J. Account. Econ. 2017, 24, 195-215.

16. Shin, B.; Han, J.; Shin, H. Human resources in internal control and auditor-client disagreement: Interaction with the requirement of submitting unaudited financial statements to the Securities and future commission. Korean Account. J. 2018, 27, 121-155. [CrossRef]

17. Suh, Y.S.; Han, J.; Shin, B.; An, J.I. The effect of human resource investment in internal control on rank-specific audit hours and audit quality. Korean Account. Rev. 2018, 43, 81-117.

18. Lee, E.C. The effect of human resource investment in the internal control on the corporate disclosure quality. Inst. Bus. Manag. 2019, 42, 309-331.

19. Chang, Y.T.; Chen, H.; Cheng, R.K.; Chi, W. The impact of internal audit attributes on the effectiveness of internal control over operations and compliance. J. Contemp. Account. Econ. 2019, 15, 1-19. [CrossRef]

20. Nam, C.H. Accrual components' predictability for future cash flows and accounting earnings. Account. Inf. Rev. 2007, 25, 221-254.

21. Farshadfar, S.; Ng, C.; Brimble, M. The relative ability of earnings and cash flow data in forecasting future cash flows: Some Australian evidence. Pac. Account. Rev. 2008, 20, 254-268. [CrossRef]

Publisher's Note: MDPI stays neutral with regard to jurisdictional claims in published maps and institutional affiliations.

(C) 2020 by the authors. Licensee MDPI, Basel, Switzerland. This article is an open access article distributed under the terms and conditions of the Creative Commons Attribution (CC BY) license (http://creativecommons.org/licenses/by/4.0/). 